\title{
MULTI-LEVEL GOVERNANCE AND INSTITUTIONAL PROCESSES FOR CLIMATE CHANGE ADAPTATION IN CITIES
}

\section{Cristina García Fernández}

Universidad Complutense de Madrid ${ }^{1}$

Daniël Peek

Universidad Complutense de Madrid²

Richard J. Dawson

Newcastle University, UK ${ }^{3}$

Oliver Heidrich

Newcastle University, UK ${ }^{4}$

https://doi.org/10.33676/EMUI_nomads.56.001

\begin{abstract}
This article describes the institutional processes for climate change in cities, focusing on different levels of governance. The research investigated the activities of the European Union (EU), national and municipal governments and citizen networks in Spain. It utilises Barcelona and Madrid as two Spanish cities that have developed and implemented responses to climate change. The article covers a relevant research gap, since there are relatively few city case studies in Spain that investigate the governance connections at different institutional levels in terms of climate change. We show how different levels of government in adaptation planning and the strength of community networks of stakeholders can do both: reduce costs and improve the efficacy of climate initiatives. The article demonstrated the need for our societies to adapt in the short and long term to address the impacts of global warming and reduce our vulnerability to this global but also very local problem.
\end{abstract}

Keywords.- Adaptation; vulnerability; adaptation strategies; sustainable cities; Public Administration; multi-level governance; urban resilience

\section{Introduction}

As adaptation to climate change is spreading across a great number of cities across Europe (Nevens and Roorda 2014; Heidrich et al. 2016), Spain (Olazabal et al. 2014) and other regions around the world (Kithiia,

1 Dr. Cristina García Fernández (corresponding author), is Professor of Applied Economics of Euro-Mediterranean University Institute (EMUI) and Universidad Complutense de Madrid (UCM), Facultad de Ciencias Políticas y Sociología, Campus de Somosaguas, 28223 Pozuelo de Alarcón, Madrid

2 Daniël Peek (MSSC) is a Junior Researcher at the Euro-Mediterranean University Institute (EMUI) and Universidad Complutense de Madrid (UCM), San Bernardo 49, 28015, Madrid

3 Prof. Richard J. Dawson is Professor of Earth Systems Engineering at the School of Engineering and Research Fellow with the Tyndall Centre for Climate Change Research, Newcastle University, Newcastle upon Tyne, NE17RU, UK

4 Dr. Oliver Heidrich is Lecturer at the School of Engineering and Research Fellow with the Tyndall Centre for Climate Change Research, Newcastle University, Newcastle upon Tyne, NEI7RU, UK. 
2010; Wilk et al. 2018), some cities have undertaken risk assessments, set emission reduction targets and introduced policies, strategies, plans and programmes to tackle climate change mitigation and adaptation issues in a coherent manner (Hunt and Watkiss 2011; Carmin et al. 2012; Reckien et al. 2015).

Through local policies and regulation, participation in national programmes, and membership in transnational networks, cities have been shown to play an important role in the configurations of climate change governance beyond their city boundary and the nation-state (Fisher, 2014).

Keivani (2010) outlines six main challenges to urban sustainable development, one of those being multi-level governance and institutional development, when in fact, streamlined horizontal and vertical governance should comprise flexible and strategic responses to address future uncertainties in the current context of climate change and globalisation. Therefore, by studying the role that the Spanish and European institutions play in the adaptation policies we will be able to understand where funding comes from in both cities and also how these funds are applied to develop the different strategies and implement the measures.

Many European countries have National Adaptation Strategies (Reckien et al. 2015; Heidrich et al. 2016) and guidance is available (ClimateADAPT 2017). But it is at a city level where most of the impacts will take place and where adaptation strategies are needed. Cities contain the largest concentration of built-up impermeable areas and high population density in a relatively concentrated space.

Therefore, interaction between the different levels of Public Administration and their communities is key to successful adaptation measures, as initiatives by local communities complement the strategies outlined by national governments, increasing the overall breadth of action and needed resources (Archer et al. 2014).

The Spanish Office for Climate Change (Oficina Española de Cambio Climático, OECC) regulates adaptation to climate change through the National Climate Change Adaptation Plan (PNACC) (OECC 2008). Although the national framework is key for the climate change guidance in Spain, other levels of goverment like the Autonomous Communities, provinces and municipalities also have an important role in climate change policy, dealing currently with particular tasks and achieving a relevant role in supporting the Central Goverment regarding climate decision-making (De Gregorio Hurtado et al. 2014). Madrid and Barcelona have been working on adaptation for two decades and their goal is to be one step forward in urban aspects and, therefore, become city leaders in Mediterranean Regions. Their experiences, processes and strategies in climate change adaptation can be exemplary for other cities. 


\section{Research need and scope}

There is an emerging literature that addresses climate change impacts at the city-scale, where, in many cases, we can find the formulation of appropriate responses (Nevens and Roorda 2014). Although quantification of risks is increasing as city authorities and other stakeholders move from raising awareness of these risks to designing responses, most studies to date have been primarily in qualitative terms (Hunt and Watkiss 2011). Dodman et al. (2017, p. 98) assert that the utilization of natural resources and the exposure to climatic risks depends on 'the quality of infrastructure, reliability of service provision and other economic and political conditions'. The two Spanish cities, Madrid and Barcelona, make important case studies as both are highly vulnerable to different risks i.e. flooding from sea level rise, draught and contamination.

The Catalan Office for Climate Change (Oficina Catalana del Canvi Climàtic) (OCCC 2012) identified that the average annual temperature in Barcelona will rise between $0,8^{\circ} \mathrm{C}$ and $1,8{ }^{\circ} \mathrm{C}$ for $2001-2050$ in comparison to 1971-2000. As a result, the summers will become drier (a $5,4 \%$ reduction of precipitation between 1950-2011 has already been observed) and hotter (a $7 \%$ rise in tropical nights in comparison to 19712000), while winters will suffer less frost days (a decrease of $5 \%$ compared to 1971-2000). In addition, the adaptation plans of the OCCC and the Barcelona Metropolitan Area (Àrea Metropolitana de Barcelona-AMB) state that a $4 \mathrm{~cm}$ per decade rise in sea levels has been observed in the Catalan coastal town of L'Estartit between 1990 and 2011 and that also the sea temperature of all measured depth levels has been rising (OCCC 2012; AMB 2015). Sea level rise is already causing floading, salt intake in aquifers and other impacts that we analyse for the case of Barcelona. In Spain, several studies have been focused on the increase in sea level on the Spanish coast (Gutierrez M and Gutierrez F 2014; Losada, et al. 2014; OECC 2015), yielding growth rates between 2-3 mm per year over the last century with significant variations in the Mediterranean basin caused by regional effects.

For Madrid, the report Vulnerability towards Climate Change on a Local Level of the Spanish Network of Cities for the Climate (Red Española de Ciudades por el Clima) (RECC 2010), indicates the need for adaptation measures in Spanish cities, especially in water management, but also in agriculture, biodiversity, health and tourism. This network belongs to the Spanish Federation of Municipalities and Provinces (FEMP) and the Spanish Office of Climate Change (OECC), which are both integrating mitigation and adaptation to climate change into their policies. We chose this report because it provides solutions and meassures which may be implemented by local councils to tackle climate change and its effects. It also provides climate scenarios, vulnerability assesments of spanish cities and towns and specific local adaptation tools. The report estimates that the minimum temperatures of Madrid will be rising between $2,5^{\circ} \mathrm{C}$ and $3{ }^{\circ} \mathrm{C}$, being the maximum $3,5^{\circ} \mathrm{C}$ and $4^{\circ} \mathrm{C}$ in 2050 , 
compared to the period of 1961-1990, while yearly variation of precipitation is expected to decrease about $100 \mathrm{~mm}$ in the same period (idem 2010). These data are also shown in the Plan for Sustainable Energy Use and Prevention of Climate Change (MCC 2014b), the institutional framework for adapatation in Madrid, which itself underpins that adaptation measures in water resources, health, green spaces and buildings are the top priorities of the city. In April 2016, the City Council of Madrid and the Autonomous University of Madrid published a detailed study of Madrid's urban climate (Fernández García et al. 2016), which attests the rise in temperatures, heat waves and the Urban Heat Island effect within the last 15 years.

In Barcelona, the Citizen Commitments define the institutional framework for adaptation to climate change. The City Council outlined the sustainable development objectives in the Citizen Commitment to Sustainability 2002-2012 and idem 2012-2022 (BCC 2002; BCC 2012). The role of the City Council in these Commitments is to strengthen the network of participating organizations by means of a complete program of exchange activities, shared projects and visits, while also providing assistance and funding to help the participants to execute their specific plans of action in accordance with the outlined strategic objectives.

Already many European cities are implementing low cost climate downscaling methods to tackle adaptation. But while low cost climate downscaling applications would be useful in future research, the greatest priority is to develop responses that can work within the high uncertainty of future climate change, to build resilience and maintain flexibility (Hunt and Watkiss 2011).

\section{Research method}

Rooted in grounded theory, as outlined in Hunter and Kelly (2008), Charmaz (2006) and Glaser and Strauss's (1967), we developed a research strategy based on case studies. This allowed us to elaborate an exploratory research through systematic data collection that corresponds to the reality of adaptation measures in both Spanish cities, which, in turn, can orientate cities around the world in developing their own adaptation mechanisms.

This method serves to get a clear overview of the current institutional role that apply to the cities, giving the researcher an opportunity to capture how climate change impacts differ per region and what measures have been undertaken to tackle potential impacts. Exploratory research is not intended to provide conclusive evidence, but helps us to have a better understanding of the problem. Therefore, adaptation strategies coming from the European and National levels provide insights into the general vulnerabilities, risk assessments and proposed guidelines, whereas the adaptation strategies developed at a regional level give an 
understanding of the practical implementation of the adaptation efforts and their details, such as funding and the responsibilities of each stakeholder. We consulted a wide range of relevant academic literature to bolster our analysis. Some examples are Dodman et al. 2017; Fisher et al. 2014; Keivani 2010; Kithiia 2010 and Wilk et al. 2018. We have also analysed institutional and legislative literature. We gathered urban climate change responses in the form of strategic policy and planning documents approved or published by the municipal authorities or published in climate change adaptation plans.

As adaptation efforts of both cities go back af least two decades, we were able to obtain relevant literature relating to adaptation measures that have already been implemented, and therewith, assessments of the results. This research method and the collected data provide a solid base for the analysis and interpretation of the state of adaptation measures in Barcelona and Madrid, theorizing into an interesting discussion.

\section{Results}

\subsection{Institutional processes for Climate Change Adaptation in the European Union}

With regard to the institutional framework of climate change adaptation, international declarations, such as those resulting from the United Nations (UN) provide the most general guidelines on sustainable development and diagnoses of vulnerability assessments, but 'as climate change is a transversal issue, needs, responsibilities, strategies and finances must be comprehensively assessed across multiple scales, administrative levels and sectors' (Wilk et al. 2018, p. 34). In accordance with these international agreements, the European Union (EU) is the next step for a more continental approach in addressing climate change, especially when it comes to cross-border impacts and sectors that are integrated at the EU. However, due to differences in vulnerabilities and impacts of climate change among Member States, most of the adaptation efforts are made at the national, regional or local level. Local communities can provide valuable observations regarding the practical implementation of adaptation measures but mechanisms are required at the national and EU level to allow that these insights are to be taken into account at the policy-making process (Archer et at. 2014).

Adopted by the European Commission (EC) in 2013, the EU Strategy on adaptation to climate change is the framework for accelerating mechanisms to improve Europe's resilience to climate change. For instance, the Commission provides guidelines to encourage every Member State to adopt a comprehensive adaptation strategy. It also provides tools to share knowledge on climate adaptation, such as the European Climate Adaptation Platform (Climate-ADAPT) and the 
introduction of adaptation in the Covenant of Mayors framework, Mayors Adapt.

Financial constraints are considered as one of the major obstacles that the authorities experience when implementing adaptation measures (COM 2009). Many adaptation initiatives are costly and do not generate revenue. Therefore, next to the guidance on adaptation policy-making, the EU also plays a crucial role in overcoming this major obstacle by providing funding for adaptation meassures (Mendizabal et al. 2018). The EU institutions agreed that at least $20 \%$ of the total EU budget should be invested in climate action for 2014-2020 (EC 2013), by which the five European Structural and Investment Funds 5 have also integrated adaptation into their policies. The LIFE Programme for the Environment and Climate Change 2014-2020 is an additional financial instrument established by the European Commission that supports environmental projects and climate action in all sectors of the European economy, which includes a budget of 864 million euro used for mitigation and adaptation efforts in this period (idem 2013). Furthermore, authorities can also obtain financial resources and loans for climate adaptation from two aditional institutions, the European Investment Bank (EIB) and the European Bank for Reconstruction and Development (EBRD).

The transfer of financial resources from the European Union Funds is done through the Cohesion Policy, a tool which aims 'to continue helping the poorer regions of the EU catch up, to facilitate coordination between EU policies, and to develop cohesion policy into a leading enabler of growth, also in qualitative terms, for the whole of the EU, while addressing societal challenges such as ageing and climate change' (COM 2010, p. $2)$. The EU Funds are programmed for several years and available funding depends on the percentage of a Member State's GDP compared to the European average.

Partnership agreements between the EC and individual EU countries set out the national authorities' plans on how to use funding from the European Structural and Investment Funds. They outline each country's strategic goals and investment priorities, linking them to the oyerall aims of the Europe 2020 Strategy for Smart, Sustainable and Inclusive growth (EC 2010). For example, the European Regional Development Fund (ERDF) funds plans and programmes of a certain region, whereas, in contrast, the Cohesion Fund (CF) finances specific individual projects (CIII 2014). Each funding request has to be presented to the EC, which will then consider its approval or rejection.

In the fifth conclusion report on the Cohesion Policy, the EU states that the policy contributed to the creation of jobs, improved environmental protection and aided in the construction of critical infrastructure (COM

5 European Regional Development Fund (ERDF), European Social Fund (ESF), Cohesion Fund (CF), European Agricultural Fund for Rural Development (EAFRD), European Maritime and Fisheries Fund (EMFF). 
2010). However, the EU is also aware that further improvements are necessary for the Cohesion Policy to move towards a more resultsoriented approach, ensuring that funding granted is properly designated. Measures to improve the Cohesion Policy include streamlining the policy, improving performance through conditionality and incentives, ongoing evaluations and strengthening multi-level governance with a specific call for an Urban Agenda, as cities are considered to be hubs for innovation and engines for growth (idem 2010).

\subsection{Institutional processes for Climate Change Adaptation in Spain}

The Spanish Office for Climate Change (OECC), founded in 2001, is the main institution that coordinates the national adaptation policies. It belongs to the Ministry of Agriculture, Food and Environment (MAGRAMA) and has a direct connection with the rest of organisms and institutional agents of Spain in different levels of competence (regional and local). Among its priorities, it promotes the integration of adaptation to climate change in the planning of sectoral policies.

At a national level, the OECC grants funding (through specific projects 'Clima Projects') to public administrations, non-governmental organizations, institutions, public and private entities and other social agents. It also collaborates on initiatives related to climate change with the European institutions.

At the EU level, a representation of the Ministry participates in collaboration programmes and assumes the follow-up of international conventions in the areas of its competence, in particular, exercising as a national focal point in the United Nations Framework Convention on Climate Change (UNFCC) and in the Intergovernmental Panel on Climate Change (IPCC).

Adopted in 2006, the National Climate Change Adaptation Plan (PNACC) is 'the reference framework tool for the coordination of Public Administrations' efforts in dealing with the assessment of impacts, vulnerability, and adaptation to climate change' (OECC 2008, p. 1). Already in 2014, the third monitoring report on the PNACC was published, and since 2015 its Third Working Programme is being carried out.

In 2007, a Strategy on Climate Change and Clean Energy was passed. In 2013, the National Plan on Air Quality and Clean Energy as well as the fifth version of the National Plan for the Prediction and Vigilance of Adverse Meteorological Phenomena were adopted. In 2016, the State Budget included 93 million euros for the Plan to Impulse the Environment (Plan de Impulso al Medio Ambiente, PIMA), which ensures environmental improvements in various sectors, leading to new jobs and economic growth (OECC 2016). PIMA Transport, PIMA Land, PIMA Air, PIMA Sun, PIMA Waste, PIMA Adapt and PIMA Business all have separate 
budgets and objectives allocated. Among the achievements, waste is now being collected separately per each 60.000 inhabitants (PIMA Waste) and approximately 33.200 tons of $\mathrm{CO} 2$ are now being reduced (PIMA SUn).

At the regional level, the Autonomous Communities (AC) are implementing a relevant number of mitigation and adaptation measures, which were formerly adopted by the Central Government for different sectors (Olazabal et al. 2014). Presently, all the AC have formalized their climate action through the development of a climate change strategy and the creation of specific entities to deal with energy matters. The $A C$ are supporting the action of cities in a wide range of sectors and are considered to have an important role in fostering climate change at a city level. At the local level, the Spanish Network of Cities for the Climate (Red Española de Ciudades por el Clima - RECC) is a technical assessment tool for Spanish local governments that works to promote the coordination of measures between them (RECC 2010). The local proactive action developed by the Spanish cities has helped to improve the overall climate performance in Spain.

\subsection{Institutional processes for Climate Change Adaptation in Barcelona}

In 2013, Barcelona obtained recognition from the United Nations as an international role model city for its focus on urban resilience (UNISDR 2013). As the city is ambitious in climate change adaptation, Barcelona is very active in implementing policies and collaborating on diverse projects at European, national and regional levels. On this line, the city takes part in the Covenant of Mayors, Mayors Adapt and other European programs.

As an Autonomous Community, Catalonia has its own government. The Generalitat de Catalunya is the highest authority within the Catalan territory. In 2006, the Catalan Office of Climate Change (OCCC) was set up to give a regional impulse to the implementation of environmental policies. This led to two mitigation plans (2008-2012 and 2012-2020) and the Catalan Strategy for Adaptation to Climate Change: Horizon 20132020. In this adaptation plan, 63 climatic impacts have been analysed, 182 adaptation measures elaborated and various socio-economic sectors determined. Of these sectors, water management is by far the most vulnerable sector (OCCC 2012).

More locally, the Provincial Council of Barcelona (Diputació de Barcelona) covers the 311 municipalities of the province. The smaller municipalities are also very active in tackling climate change. The Ajuntament de Barcelona (Barcelona City Council - BCC) is the main administration with political responsibilities in the city. The Àrea Metropolitana de Barcelona (AMB) is the supra-municipal entity of the metropolitan area and has its own competences in sectors such as 
cohesion, transport and environment. These public administrations have departments that regulate environmental policymaking, like the Consell Municipal de Medi Ambient $i$ Sostenibilitat (Municipal Council of Environment and Sustainability) of the Barcelona City Council.

Responsible institutions for water management in Barcelona are mostly public entities, being the Catalan Water Agency (Agència Catalana de l'Aigua - ACA) the highest authority, whereas Aigües Ter Llobregat (ATLL) is the owner of the distribution network and water treatment plants. Both are owned by the Catalan Government (Techneau 2010). Water is distributed to the citizens through Aigües de Barcelona, a company in charge of managing services related to the integral water cycle, such as the supply of potable water and sewerage.

The competencies of the various levels of Public Administration in sustainability management in Barcelona are divided through the principle of shared responsibility. In the case of urban mobility, the Catalan Government owns the transportation infrastructure, such as the metro, railways, roads and tram. However, it is the Metropolitan Area that manages the services, also including bus and taxi services but with the exception of regional trains. In turn, the Barcelona City Council has the responsibility to assure proper safety and flow of traffic and has it own competences regarding bicycles and pedestrians (BCC 2015). In the case of urban planning, the AMB has overall responsibility since the approval of the Barcelona's Metropolitan Spatial Plan by the Catalan Goverment (AMB, 2015). Table 1 further illustrates the responsibilities of the Catalan Government, the AMB and the Barcelona City Council.

Table 1: Responsibilities for sustainability in Barcelona (AMB 2015; BCC 2015).

\begin{tabular}{|c|c|c|c|}
\hline $6 x^{2}$ & $\begin{array}{l}\text { Catalan } \\
\text { Government }\end{array}$ & $\begin{array}{l}\text { Metropolitan } \\
\text { Area }\end{array}$ & $\begin{array}{l}\text { Barcelona City } \\
\text { Council }\end{array}$ \\
\hline Sustainable building & & - & - \\
\hline $\begin{array}{l}\begin{array}{l}\text { Protection of the } \\
\text { atmosphere }\end{array} \\
\text { a }\end{array}$ & & - & \\
\hline Urban mobility & - & - & - \\
\hline Urban planning & 0 & - & \\
\hline Street lighting & & & - \\
\hline Waste treatment & & - & - \\
\hline
\end{tabular}

- The Catalan Government gives the final approval to the Metropolitan Area.

Barcelona was relatively early involved in developing sustainable principles. In 1994, the City Council signed the Aalborg Charter of Sustainable Cities \& Towns towards Sustainability (Franquesa 2012), inspired in the 1992 Rio Earth Summit. 
The establishment of the Municipal Council for Environment and Sustainability (1998) gave rise to the elaboration of the Citizen Commitment to Sustainability 2002-2012 which was passed in May 2002 by the City Council. It is based on the philosophy of shared responsibilities, aiming to bring forth 'a better socio-economic organization, the implementation of more efficient technologies, and especially, changes in civic attitudes' (BCC 2002, p. 3). The Commitment outlines 10 clear objectives, ranging from the protection of open spaces and biodiversity to the preservation of natural resources and promotion of renewable energy, each coming with a diagnosis and 10 specific lines of action. It has become the reference point for the environmental objectives of Barcelona. The Commitment has since then been signed by about 800 civic organizations, half of which are educational institutions, with thousands of participating citizens (Franquesa 2012).

Some important fulfilled objectives of the initial Commitment include $100 \%$ treatment of wastewater, the introduction of organic waste collectors, savings in water consumption per inhabitant and a quantum leap in the use of solar energy (BCC 2012). Great progress has been made in widening green spaces or the use of renewable energy, while little progress was made in air and noise pollution (Franquesa 2012).

Despite of the fact that Barcelona does not have a Climate Change Adaptation Plan as such, the Citizens Commitments serve the same principle. In the wake of these Commitments, both the OCCC (2012) and the AMB (2015) elaborated their own Adaptation Plans.

The protection of open spaces and biodiversity and the expansion of green infrastructure has been the first objective in the initial Citizens Commitment of 2002. The biggest share of funding for green infrastructure comes from the public administrations. In 2017, the City Council spent 60.951 .240 euro $(2,23 \%$ of the total City spending) to climate action, of which $1,85 \%$ was designated to green infrastructure and biodiversity (BCC 2018). The Barcelona Green Infrastructure and Biodiversity Plan 2020 states that human and financial resources have been allocated through the local citizen's commitments, being one of the goals to secure more financial support from economic stakeholders (BCC 2013). The network established by the Commitments proves to be an additional source of funding, as stakeholders could provide part of the funds through small projects, directly improving their own neighbourhood.

The availability of potable water in Barcelona 'has been long characterized by the constant search for resources to meet an evergrowing demand from industrial and especially residential uses in a context of recurring hydrological stress' (Domene and Saurí 201 1, p. 33). According to the OCCC (2012), water management is the most vulnerable sector, and also, the $A M B$ and the $B C C$ outline that an 
increase in water demand will be a major challenge (AMB 2015; BCC 2015).

The ACA main source of financing is the Cànon de l'Aigua (Water Tax). This water tax has been implemented for the entire Catalan Autonomous Community in the year 2000, has a progressive structure and an environmental purpose (Domene and Saurí 2011). However, the Cànon de I'Aigua has only covered half of the public expenses and investments of the ACA, since this agency's debt reached 1,5 billion euros in 2010 (March and Saurí 2013). Moreover, the authorities are often forced to take urgent action with no time to find proper funding in periods of drought, leading to massive economic costs (Techneau 2010).

The Cohesion Fund (CF) and the European Regional Development Fund (ERDF) have co-funded various projects in Catalonia. Between 2000 and 2006, 108 projects of the ACA of a total of 177.59 million euros enjoyed $50 \%$ ERDF funding, whereas between 2004 and 2011, 10 individual projects of a total of 434.47 million euros got between $68 \%$ and $85 \%$ of the CF funding (ACA 2018).

There is an institutional and academic consensus that the costs of environmental improvement of water management should be internalized by spreading all costs evenly among users, but this has not always been well-accepted by the consumers. Most citizens consider water as a public good and, therefore, they request it to be subsidized. However, the 'Catalan political and economic elites launched the message that the only "natural" way out of the delicate economic situation of the ACA is to pass costs on to consumers (increasing water pricing and taxation) and to open the door to a higher degree of private participation in the water cycle' (March and Saurí 2013, p. 2077).

In order to meet the continuously growing demand of potable water in the Barcelona Metropolitan Area, innovative ways of creating additional water supply have been adopted. The salt water resources of Mediterranean Sea proved to be a solution to cutback water scarcity in the area. In July of 2009, a Seawater Reverse Osmosis plant (SWRO) was opened at the shores of the Llobregat River. The project had a cost of 230 million euro and was funded by the EU Cohesion Fund (80\%) and MAGRAMA.

Finally, the coastal city of Barcelona is facing a high risk of flooding, as a $4 \mathrm{~cm}$ rise per decade has already been observed by the Catalan institutions (OCCC 2012). The Integrated Coastal Management Programme of Barcelona is the annually renewed guide for managing the coastline. Management and coordination is carried out through this Programme, which is led by the Service Office for the Water Cycle of the Barcelona City Council. 


\subsection{Institutional processes for Climate Change Adaptation in Madrid}

The involvement of the city of Madrid in climate matters goes, at least, back to 1999, when the Inventory of Contaminant Emissions for the Atmosphere was established. Madrid has been very eager in introducing mitigation and adaptation measures to tackle climate change. The City Council actively cooperates on the EU level. It is one of the founding members of the Covenant of Mayors, signed in 2009, and also participates in Mayors Adapt.

Madrid is located in the most densely populated Autonomous Community of Spain. The Community of Madrid is basically the metropolitan area of Madrid and has its own parliament and, therewith, own competences. Unlike Catalonia, the Community of Madrid does not have a provincial level but consists directly of 179 municipalities. The Área de Gobierno de Medio Ambiente y Movilidad (Government Area of Environment and Mobility) of the City of Madrid is the main department regulating environmental policy at the local scale. With regard to water management, Canal de Isabel II (CIII) is the responsible institution, which is owned by the Community of Madrid.

The Plan for Sustainable Energy Use and Prevention of Climate Change Horizon 2020 of the City of Madrid (MCC 2014b) outlines the legal and institutional framework within which the city is able to implement its climate change adaptation and mitigation policies. This plan is the successor of the initial 2008 version, which goes under the same name. The City Council of Madrid is aware that climate change prevention and energy efficiency are among the main challenges for the city, and therefore, considerable effort is being made through measures designed to address both objectives. Additionally, the framework is elaborated in line with Europe 2020 Strategy for Smart, Sustainable and Inclusive growth of the European Union, and therewith, follows the same objectives.

According to the Plan for the Sustainable Use of Energy and Climate Change Prevention for the City of Madrid, municipal policy should take into account the local strategies, policies and legal framework on matters of climate change and GHG emissions, without ignoring those relating to the energy sector (idem 2014). As regards to climate change, the Central and Regional Governments use measures and tools of a general nature, comprising very broad sectoral boundaries.

The Local Government Regulatory Law 7/1985 establishes that municipalities have jurisdiction to carry out activities complementary to those of other public administrations regarding the general interest of the city, in particular protecting the environment.

One of the key measures of the municipal planning of Madrid, carried out by the Madrid City Council, is to promote knowledge of the causes and effects of urban climate change. This initiative has the purpose to anticipate urban impacts and to tackle any possible adaptation 
measures in order to minimize or prevent them. To achieve this goals, a series of emission abatement measures are proposed in five sectors of activity (residential, commercial and institutional, transport, waste management, industry and sinks), together with transversal and adaptation measures.

With regard to the responsibilities in sustainable management, the City Council faces several barriers in its capacity to act. For example, it cannot take decisions about technical aspects of construction, renovation and integration of renewable energy in buildings. These kinds of measures regarding urban planning need the approval of the Community of Madrid as outlined in the General Plan of Urban Order of Madrid (MCC 2010). Nevertheless, the city council can influence sustainable building by other means. For example, the local government can install solar energy sources in its own buildings, but it also tries to incentivise the promotion of renewable energies through taxation within the established limits outlined by the Spanish State, and encourage rehabilitation in parks by granting subsidies among other campaigns (MCC 2014b). In the area of the protection of the atmosphere, municipalities with more than 100.000 inhabitants are required to adopt their own plans in order to comply with the objectives for improving air quality, as outlined in the Spanish State legislation (idem 2014b). Moreover, the City Council and the municipalities enjoy full competences on creating plans relating to urban mobility, which are being set in Madrid through the Plan of Sustainable Urban Mobility. Table 2 further illustrates the responsibilities of the Community of Madrid, the City Council and the Municipalities.

Table 2: Responsibilities for sustainability in Madrid (MCC 2014b)

\begin{tabular}{|l|l|l|l|}
\hline & $\begin{array}{l}\text { Community of } \\
\text { Madrid }\end{array}$ & $\begin{array}{l}\text { Madrid City } \\
\text { Council }\end{array}$ & Municipalities \\
\hline $\begin{array}{l}\text { Sustainable building } \\
\text { Protection of the } \\
\text { atmosphere }\end{array}$ & $\bullet$ & $\bullet$ & $\bullet$ \\
$\begin{array}{l}\text { Urban mobility } \\
\text { Urban planning }\end{array}$ & 0 & $\bullet$ & $\bullet$ \\
\hline $\begin{array}{l}\text { Street lighting } \\
\text { Waste treatment }\end{array}$ & & $\bullet$ & $\bullet$ \\
\hline
\end{tabular}

- The Autonomous Community of Madrid gives the final approval to the Madrid City Council.

In almost 20 years of initiatives to tackle climate change, the Community of Madrid and the Madrid City Council introduced, approved, implemented and revised a great number of action plans, local legislation and monitoring tools. We mention the most important ones: 
- $\quad$ Municipal Plan for the Management of Water Demand in Madrid (MCC 2005).

- Ordinance of Management and Efficient Use of Water in the city of Madrid (MCC 2006).

- Handbook for Good Practices in Architecture and Urban Planning for Madrid (MCC 2009).

- $\quad$ Plan for Air Quality of the City of Madrid (MCC 2011).

- Plan for Sustainable Use of Energy and Climate Change Prevention (MCC 2014b).

- $\quad$ Plan for Sustainable Urban Mobility of the City of Madrid (MCC 2014a)

Madrid is most affected by the rise in temperature. Greenhouse gases generated from the transportation and energy sector contribute to these increases. Therefore, one of the main goals of the Plan for Sustainable Use of Energy and Climate Change Prevention is to reduce $35 \%$ of greenhouse gas emissions in 2020, compared to 2005' (MCC 2014b, p. 25). The local government is fulfilling a variety of measures to reduce energy consumption. For instance, a Rehabilitation Commission (Mesa de Rehabilitación) has been set up, which aims to improve the living conditions of neighbours, reduce emissions to the environment and generate jobs, investing more than 138 million euro on buildings maintenance, and 25 million in form of public subsidies (MCC 2015). To be able to achieve this, the Mesa brings together various stakeholders, such as professional associations of architects, property managers, foundations, the industrial sector and neighbourhood associations which are coordinated at the regional level by the Community of Madrid.

Urban heat waves and high contamination episodes are also a public health problem, since they could increase mortality rates of vulnerable social groups, like the elderly or the disabled. Protection systems against extreme heat events should be customised to the local or regional needs, as impacts may differ in level of exposure to extreme heat and sensitivity of certain social groups but also according the local adaptive capacity to fake action, for example, in line with the availability of health and transportation facilities (Berry et al. 2014). For instance, cities have more hospitals in a relatively close range in comparison to rural areas, meaning that vulnerable groups, like the elderly, can receive better care more quickly during a heat wave. According to the Plan for Sustainable Use of Energy and Climate Change Prevention, there are two major measures in place to manage public health; the System for Health Surveillance of Environmental Risks and an Alert System for Environmental Health (MCC 2014b). The City of Madrid collaborates with the Autonomous Government in its implementation.

Madrid, with 5.947 hectare of public green areas and natural parks, wants to grow even greener (MCC 2016). Green spaces help to regulate 
the temperature, renew air and raise the city's resilience against pollution. With the help of stakeholders, the City Council, responsible for these spaces, usually take two kinds of actions: study the different species in natural parks in order to help them adapt to climate change and plant more trees in the city to reduce the Urban Heat Island Effect. In 2017, the City Council spent 205.795 .460 euro $(3,90 \%$ of the total City spending) on climate action, of which $2,71 \%$ was designated to green infrastructure and biodiversity (MCC 2018).

Finally, improving water quality and management of public irrigation is another main point of action of the city of Madrid (MCC 2006). Canal Isabel II, owned by the Community of Madrid, is the responsible company for managing the water cycle and implementing water saving measures in order to adjust the watering schedule to climatic needs in the region. Between 2000 and 2009, Canal Isabel II has allocated 2.269 billion euro to the improvement and maintenance of the Madrilenian water infrastructures. Of this amount, 217.14 million euro was provided by the EU Funds $(59,42 \%$ by the Cohesion Fund and $40,58 \%$ by the ERDF), just under 10\% of total spending, with 95 funded projects (CIII 2014). The funding of the Cohesion Fund has been used to construct the M-40 water way, a $145 \mathrm{~km}$ underground network of storage tanks that are interconnected through the water treatment plants. The M40 water way aims to save potable water by using recycled water to irrigate public parks and streets, therewith reducing waste of hydrological resources in Madrid.

\section{Discussion}

As a result of our institutional analysis, we have observed that many adaptation initiatives at the local, regional, national and European level are already in place. The European Union offers general strategic guidelines and a more supporting approach in addressing climate change on the continental level (EC 2013). The EU also plays an important role in the realization of ambitious adaptation projects, such as the M-40 water way in Madrid and the SWRO in Barcelona. The EU is sharpening the Cohesion Policy towards a results-oriented approach to assure that funding provided is well-designated (COM 2010). At the national level, the Spanish Government provides insights into the vulnerabilities, risk assessments and proposed guidelines through the Spanish Office for Climate Change, which, in turn, also implements certain concrete actions, for example through the PIMA Plans (OECC 2008; OECC 2015). At the regional level, the Catalan Office for Climate Change gives a regional impulse towards climate change adaptation in Catalonia, identifying regional vulnerabilities, proposing measures and elaborting adaptation strategies (OCCC 2012). The Community of Madrid provides support to adaptation initiatives, has its own competences and is bringing together various stakeholders, such as 
through the Mesa of Rehabilitation for sustainable building (MCC 2015). At the local level, both the Barcelona City Council and the City Council of Madrid, have extensive adaptation plans in place and are the main actors with regard to the implementation of adaptation efforts (BCC 2012; MCC 2014b). Although the adaptation plans at all levels are, to a good extent, in line with each other, we observed differences in the practical execution of adaptation measures in the local and regional frameworks, such as the way urban mobility is handled by both cities, which implies a certain lack of coordination between different levels of Public Administration.

Furthermore, we have realised that civic attitudes and the strength of a network are crucial for an adaptation mechanism to work (Franquesa 2012; MCC 2015). Initiatives by local communities complement the policy-making process, through valuable observations and experience with practical implementation (Archer et al. 2014). The support of the community has the potential to accelerate adaptation efforts, which became clear through the Citizens Commitments of Barcelona and the Mesa of Rehabilitation of Madrid. Therefore, adaptation mechanisms being implemented by local authorities should address changes in civic attitudes, for example through campaigning and education. The network that arises through the mobilization of the community, should be embraced by all levels of Public Administration, and could provide the much-needed inclusion of other financial stakeholders, such as the private sector, to take their share of responsibility. Establishing this network 'will provide a stronger source of support and ensure a meaningful engagement with the state institutions in a synergistic mutually supportive state-community relationship' (Kithiia 2010, p. 29.)

We believe that for an adaptation mechanism to be successful there will be a need for a proper interface that allows the exchange of knowledge between the national-supranational (EU) level and the regional-local level, even up to the point that cities from different countries can learn from each other (Mendizabal et al. 2018). On one hand, this means that the national and supranational level should develop mechanisms in which the insights of the local communities are shared and taken into account during the development of the overall adaptation strategies. On the other hand, regional and local authorities should fully explore and take advantage of the support that is being provided by the national and European institutions. By creating an atmosphere of collaboration and sharing of best practices, the network to address climate change adaptation will grow exponentially, leading to more innovative measures and to the availability of resources. Urban adaptation is a learning process, 'yet cities also provide the greatest promise and potential for addressing many of these challenges' (Keivani 2010, p. 13). 


\section{Conclusion}

We have learnt that planning for adaptation in these cities, in Spain and elsewhere is a dynamic process. We have demonstrated that involving different levels of government and the local community in adaptation planning can reduce costs and improve the efficacy of measures. It is critical to understand that while economic and human impacts affect cities disproportionately, adaptation measures often need planning beyond municipal borders to be effective, as in the case of water management. Therefore, adaptation and policy making should be streamlined between the levels of Public Administration, while involving the practical expertise of stakeholders to strive for the best adaptation mechanisms, based on the sharing of best practices.

Adaptation ranges from single measures, through mainstreaming potential action into other policies, up to comprehensive strategic planning. But still, the prevailing approach is to prioritise easy options, like low-cost and low-regret measures executed at the local level, such as boosting green infrastructure. Most Spanish and European cities have not yet implemented comprehensive adaptation approaches that combine coping, incremental and transformative action.

The institutional frameworks analysed in this article are still developing the potential of transformative adaptation as both cities are including some climate-resilient design when regenerating urban areas. For instance, using green infrastructure to cool urban areas and the construction of sustainable buildings show that they are making great efforts to establish transition management. However, they still have a long way to go, as urban adaptation is a dynamic process. Exchanging knowledge and experience is key for climate-resilient cities and for Europe as a whole, for both beginner and frontrunner cities and for all other stakeholders.

We show that a strong interface between the different levels of Public Administration would strengthen city adaptation, especially in the case of funding, considered a main obstacle for adaptation. Regional and local institutions should, therefore, explore the extensive support programmes provided by the EU and the national governments to the fullest in order to accelerate the fulfilment of their climate objectives. Local initiatives complement policy-making at the higher levels of Public Administration and we have also realized that a strong and committed stakeholder partnership, with involvement of citizens, is vital for climate change adaptation to be effective. We have also found that climate change risk assessments developed by national and local institutions, such as the RECC, OCCC and OECC, provide relevant information to the overall institutional framework in order to address vulnerabilities more effectively.

The article presents new insights and understandings on the interlock of the European, national, regional and local policy frameworks for adaptation strategies, providing evidence of successful collaborative 
efforts in Barcelona and Madrid to tackle climate change impacts. Additionally, the call for the involvement of local communities, as many times requested by academics, has been bolstered in this paper by analysing the chosen adaptation frameworks of both cities. Through these new understandings on how Barcelona and Madrid implement adaptation measures, other urban areas will be able to evaluate and improve their own sustainability strategies and policies. We believe that the exchanging of knowledge and experiences will be essential to extend the scope of current adaptation strategies, therewith improving resilience to climate change around the world and continuing to drive research in search of the best practices.

\section{References}

[ACA] Catalan Water Agency. 2018. Información económica Actuaciones con fondos europeos 2000-2018. [Economic information Actions with European funds 2000-2018]. [accessed 2018 Mar 15]. http://aca-web.gencat.cat/aca. Spanish.

[AMB] Barcelona Metropolitian Area. 2015. Pla d'adaptació al canvi climàtic de l'Área Metropolitana de Barcelona (2015-2020) - resum executiu. [Adaptation plan for climate change of the Metropolitan Area of Barcelona (2015-2020) - executive summary]. Environmental Services Directorate of the AMB. Barcelona. Catalan.

Archer D, Almansi F, DiGregorio M, Roberts D, Sharma D, Syam D. 2014. Moving towards inclusive urban adaptation: approaches to integrating community-based adaptation to climate change at city and national scale. Clim Dev. 6(4):345-356.

[BCC] Barcelona City Council. 2002. Citizen commitment to sustainability 2002-2012. Municipal Council on the Environment and Sustainability. Barcelona.

[BCC] Barcelona City Council. 2012. Citizen commitment to sustainability 2012-2022 - For a more equitable, prosperous and self-sufficient Barcelona. Barcelona.

[BCC] Barcelona City Council. 2013. Barcelona green infrastructure and biodiversity plan 2020. Commission of Urban Habitat and Environment. Barcelona.

[BCC] Barcelona City Council. 2015. Barcelona, a city committed to the environment - Environmental report 2013. Barcelona. 
[BCC] Barcelona City Council. 2018. Open Budget - Budget Detail. [accessed 2018 Mar 17]. http://ajuntament.barcelona.cat/estrategiaifinances/pressupostobert/e $\mathrm{n} /$.

Berry P, Yusa A, Morris-Oswald T, Rogaeva A. 2014. Heat alert and response systems in urban and rural communities in Canada. Chan Adapt Soc-Eco Syst. 1:84-97.

Charmaz K. 2006. Constructing grounded theory: A practical guide through qualitative analysis. Sage Publications. London (UK).

[CIII] Canal de Isábel II. 2014. Europe invest in your water: European Union funds used in the management of the Community of Madrid integral water cycle (2000-2010). M-22731-2014. Madrid.

Carmin J, Nadkarni N, Rhie C. 2012. Progress and challenges in urban climate adaptation planning: Results of a global survey. MIT. Cambridge (MA).

Climate-ADAPT. 2017. European Climate Adaptation Platform. [accessed 2017 Oct 9]. http://climate-adapt.eea.europa.eu/

[COM] Commission of the European Communities. 2009. White paper Adapting to climate change: Towards a European framework for action. 147/4. Brussels.

[COM] Commission of the European Communities. 2010. Conclusions of the fifth report on economic, social and territorial cohesion: the future of cohesion policy. 642. Brussels.

De Gregorio Hurtado S, Olazabal M, Salvia M, Pietrapertosa F, Feliú E, Olazabal E, Reckien D, et al. 2014. Multi-level climate governance and urban climate action. In Dawson RJ, Wyckmans A, Heidrich O, Köhler J, Dobson S, Feliú E, (eds.). Understanding Cities: Advances in integrated assessment of urban sustainability. Final report of COST action TU0902:7788. Newcastle: Centre for Earth Systems Engineering Research (CESER).

Dodman D, Diep L, Colenbrander S. 2017. Making the case for the nexus between resilience and resource efficiency at the city scale. Int J Urban Sustain Dev. 9(2):97-106.

Domene E, Sauri D. 2011. Water, public responsibility and equity: The Barcelona 'water war' of the 1990's. In Barraque B. Urban water conflicts: UNESCO-IHP:33-37. Boca Raton (FL). CRC Press.

[EC] European Commission. 2010. Europe 2020: A strategy for smart, sustainable and inclusive growth. COM 2010. 2020 final. Brussels.

[EC] European Commission. 2013. The EU strategy on adaptation to climate change. Brussels.

Fernández García F, Allende Álvarez F, Alcaide Muñoz J, Rasilla Álvarez D, Martilli A. 2016. Estudio de detalle del clima urbano de Madrid. 
[Detailed study of the urban climate of Madrid]. Government Area of Environment and Mobility. Madrid. Spanish.

Fisher S. 2014. Exploring nascent climate policies in Indian cities: a role for polics mobilities?

HYPERLINK "https://www.scopus.com/sourceid/21 100208039? origin=recordpage" \o "Go to the information page for this source" Int J Urban Sustain Dev. 6(2):154-173.

Franquesa T. 2012. Barcelona's agenda 21: 10 years of citizen commitment to sustainability. City Environ Educ:66-70.

Glaser BG, Strauss's AL. 1967. The discovery of grounded theory: strategies for qualitative research - A division of transaction publishers. Canada (NB) and London (UK). reprinted 2006.

Gutierrez M, Gutierrez F. (eds). 2014. Landscapes and landforms in Spain. University of Zaragoza. Springer.

Heidrich O, Reckien D, Olazabal M, Foley A, Salvia M, De Gregorio Hurtado S, Dawson RJ, et al. 2016. National climate policies across Europe and their impacts on cities strategies. J Environ Manag. 168:36-45.

Hunt A, Watkiss P. 2011. Climate change impacts and adaptation in cities: A review of the literature. Clim Chan. 104:13-49.

Hunter K, Kelly J. 2008. Grounded theory. In Knight A, Ruddock L (eds.). Advanced research methods in the built environment:86-98. Oxford (UK). Blackwell Publishing.

Keivani R. 2010. A review of the main challenges to urban sustainability. Int J Urban Sustain Dev. 1(1-2):5-16.

Kithiia J. 2010. Old notion-new relevance: Setting the stage for the use of social capital resource in adapting east African coastal cities to climate change. Int J Urban Sustain Dev. 1 (1-2):17-32.

Losada IJ, Izaguirre C, Díaz P. 2014. Cambio climático en la costa española. [Climate change at the Spanish coast]. Spanish Office for Climate Change. Ministry of Agriculture, Food and Environment (MAGRAMA). Madrid. Spanish

March H, Sauri D. 2013. The unintended consequences of ecological modernization: debt-induced reconfiguration of the water cycle in Barcelona. Environ Plan A. 45:2064- 2083.

[MCC] Madrid City Council. 2005. Plan municipal de la gestión de la demanda del agua en la ciudad de Madrid. [Municipal plan for the management of water demand in Madrid] Government Area of Environment and Services to the City. Madrid. Spanish.

[MCC] Madrid City Council. 2006. Ordenanza de gestión y uso eficiente del agua en la ciudad de Madrid. [Ordinance of management and efficient use of water in the city of Madrid]. Madrid. Spanish. 
[MCC] Madrid City Council. 2009. Buenas práticas en arquitectura y urbanismo para Madrid. [Handbook for good practices in architecture and urban planning for Madrid]. Government Area of Urbanism and Housing. Madrid. Spanish.

[MCC] Madrid City Council. 2010. Plan general de ordenación urbana de Madrid - 1997. [General plan of urban order of Madrid - 1997]. Government Area of Urbanism and Housing. Madrid. Spanish.

[MCC] Madrid City Council. 2011. Plan de calidad del aire de la ciudad de Madrid 2011-2015. [Plan for air quality of the city of Madrid 20112015]. Government Area of Environment, Security and Mobility. Madrid. Spanish

[MCC] Madrid City Council. 2014a. Plan de movilidad urbana sostenible de la ciudad de Madrid. [Plan for sustainable urban mobility of the city of Madrid]. Government Area of Environment, Security and Mobility. Madrid. Spanish.

[MCC] Madrid City Council. 2014b. Plan de uso sostenible de la energía y prevención del cambio climático de la ciudad de Madrid - Horizonte 2020. [Plan for sustainable energy use and prevention of climate change of the city of Madrid - Horizon 2020]. Governing Board of the City of Madrid. Madrid. Spanish.

[MCC] Madrid City Council. 2015. Nace la mesa de rehabilitación. [The rehabilitation commission is born]. [accessed 2017 Nov 2]. http://www.madrid.es/portales/munimadrid/es/Inicio/Actualidad/Notici as/ Nace-la-Mesa-de-Rehabilitacion. Spanish.

[MCC] Madrid City Council. 2016. Anuario estadístico 2016. [Statistical yearbook 2016]. [accessed 2017 Nov 6]. Www.madrid.es/estadistica. Spanish.

[MCC] Madrid City Council. 2018. Open Budget - Budget Detail. [accessed 2018 Mar 17].https://presupuestosabiertos.madrid.es/en/.

Mendizabal M, Heidrich O, Feliu E, García-Blanco G, Mendizabal A. 2018. Stimulating urban transition and transformation to achieve sustainable and resilient cities. Renew Sustain Energy Revs. 94:410-418.

Nevens F, Roorda C. 2014. A climate of change: A transition approach for climate neutrality in the city of Ghent (Belgium). Sustain Citi Soc. 10:112-121.

[OCCC] Catalan Office for Climate Change. 2012. Estrategia catalana de adaptación al cambio climático: Resumen ejecutivo - Horizonte 2013-2020. [Catalan strategy for adaptation to climate change: Executive Summary - Horizon 2013-2020]. Government of Catalonia. Barcelona. Spanish. 
[OECC] Spanish Office for Climate Change. 2008. PNACC: The Spanish national climate change adaptation plan. Ministry of the Environment, Rural and Marine Affairs (MARM). Madrid.

[OECC] Spanish Office for Climate Change. 2015. La estrategia de adaptación de la costa a los efectos del cambio climático. [The strategy of adaptation at the coast to the effects of climate change]. Ministry of Agriculture, Food and Environment (MAPAMA). Madrid.

[OECC] Spanish Office for Climate Change. 2016. Planes PIMA. [PIMA plans] Ministry of the Environment, Rural and Marine Affairs (MARM). Madrid. Spanish.

Olazabal M, De Gregorio Hurtado S, Olazabal E, Pietrapertosa F, Salvia M, Geneletti D, Reckien D, et al. 2014. How Italian and Spanish Cities are tackling climate change? A local comparative study. Basque Centre for Climate Change (BC3). Bilbao.

[RECC] Spanish Network of Cities for the Climate. 2010. La vulnerabilidad al cambio climático a escala local. [Vulnerability to climate change at local scale]. Section of the Spanish Federation of Municipalities and Provinces (FEMP) and Spanish Office for Climate Change (OECC). Madrid. Spanish.

Reckien D, Flacke J, Olazabal M, Heidrich O. 2015. The influence of drivers and barriers on Urban Adaptation and Mitigation Plans - An empirical analysis of European Cities. PLoS One. 10(8): e0135597

Techneau. 2010. Strategies for Addressing Water Shortages: Barcelona A Case Study. D 1.3.5. Marigny, France.

[UNIDSR] United Nations Office for Disaster Risk Reducation. 2013. UN recognizes Barcelona as role model city. Press Release of UNIDSR, Regional Office for Europe. Geneva. [accessed 2017 Sep 23]. https://www.unisdr.org/archive/32137

Wilk J, Jonsson AC, Rydhagen B, del Callejo I, Cerruto N, Chila G, Encinas S, Kumar A, Rani A. 2018. Assessing vulnerability in Cochabamba, Bolivia and Kota, India: how do stakeholder processes affect suggested climate adaptation interventions? Int J Urban Sustain Dev 10(1):32-48 